\title{
Palaeogene triserial planktonic foraminifera
}

\author{
D. GRAHAM JENKINS, ${ }^{1 \dagger}$ JOHN E. WHITTAKER ${ }^{2} \&$ DENNIS CURRY ${ }^{3}$ \\ ${ }^{1}$ Department of Geology, National Museum of Wales, Cathays Park, Cardiff CFI 3NP, UK. \\ ${ }^{2}$ Department of Palaeontology, The Natural History Museum, Cromwell Road, London SW7 5BD, UK. \\ ${ }^{3}$ Mallard Creek, Spinney Lane, Itchenor, West Sussex PO20 7DJ, UK.
}

\begin{abstract}
Triserial planktonic foraminiferal species from the Palaeogene are classified into the Early Danian Guembelitria, with pore mounds on the test surface, and the Early Eocene-Late Oligocene Jenkinsina, which are also microperforate but lack pore mounds. The stratigraphic and palaeogeographic ranges are discussed, the holotype of G. cretacea Cushman (the type species of Guembelitria) is reillustrated, and neotypes designated for G. danica (Hofker) and Jenkinsina triseriata (Terquem). Chiloguembelitria is shown to be a junior synonym of Guembelitria. J. Micropalaeontol. 17(1): 61-70, April 1998.
\end{abstract}

\section{INTRODUCTION}

Planktonic foraminifera with tests that are triserial throughout their ontogeny have been classified under the Suborder Globigerinina and Superfamily Heterohelicacea by Loeblich \& Tappan (1987). In the Palaeogene there are only a few species: two or three in the Early Danian with strong connections with Late Cretaceous taxa, and three in the Eocene-Oligocene. The paucity of species may be due in part to their small size (100-200 microns) and they may have been missed because the fine sediment fraction is rarely examined in detail by micropalaeontologists.

All the taxa have microperforate test walls and species of Guembelitria (Cretaceous-Early Danian) and its junior synonym Chiloguembelitria (Early Danian) can be clearly distinguished from those of Jenkinsina (Early Eocene-Late Oligocene) by the possession of pore-mounds on their test wall surfaces; this is contrary to the opinion of Loeblich \& Tappan (1987), who synonymized Jenkinsina with Guembelitria.

Guembelitria appears to be cosmopolitan but some of the species of Jenkinsina are more restricted palaeogeographically. For example, J. samwelli is restricted to the latest Eocene-Late Oligocene of the Southern Hemisphere.

In order to facilitate better identification of the species, the holotype of G. cretacea Cushman (the type species of Guembelitria) is re-illustrated, and neotypes are designated for $C$. danica Hofker (the type species of Chiloguembelitria) and Textilaria triseriata Terquem (the senior synonym of Guembelitria stavensis Bandy, the type species of Jenkinsina); there are no type specimens of $C$. danica and the remaining syntype of $T$. triseriata is badly damaged. A case has been submitted to the ICZN for this specimen of T. triseriata to be set aside in favour of our neotype. A neotype is also selected for $C$. danica.

Gallitellia vivans (Cushman, 1934) is the only living triserial microperforate planktonic species and, according to Loeblich \& Tappan (1987) it ranges back into the Pleistocene. They state that the main distinguishing features of Gallitellia are the very thin, hyaline, smooth and sparsely microperforate wall, simple aperture with no bordering lip, and occasional chamber proliferation in the adult test; these features distinguish it from both Guembelitria and Jenkinsina. According to Kroon \& Nederbragt (1990), G. vivans also lacks a tooth-plate. So far, this is the only record of a Neogene wholly triserial microperforate species. As a working hypothesis, iterative evolution has probably resulted in a number of triserial taxa in the Cenozoic.

\section{GENERA AND WALL STRUCTURE}

It has been the policy of phylogenetically minded micropalaeontologists to separate genetically unrelated groups of taxa with similar tests into distinct genera (Jenkins, 1965; McGowran, 1968; Steineck \& Fleisher, 1978). A case in point is the Palaeocene-Eocene genus Morozovella, erected by McGowran (1968) for keeled species unrelated to the Neogene Globorotalia. The advent of the Scanning Electron Microscope has also made it possible to base genera on fine wall structure differences. Thus, Olsson et al. (1992) were able to separate the Palaeocene cancellate spinose genera Eoglobigerina and Parasubbotina from the cancellate non-spinose Praemurica. Li Qianyu et al. (1995) dispute this because...'the pore-mound structure has been observed independently on several forms which are phylogenetically unrelated', but following our study we are firmly of the opinion that the presence of pore mounds in the microperforate triserial Danian Guembelitria can be used to distinguish it from the Early Eocene-Oligocene microperforate triserial Jenkinsina.

\section{PALAEOGENE TRISERIAL GENERA Guembelitria}

It has been established for some time that Guembelitria cretacea Cushman had a microperforate wall with pores situated centrally within pore mounds. Thus Olsson (1970) illustrated G. cretacea from the Palaeocene Redbank Formation of New Jersey with "typical wall structure and pore location within blunt spines'. Smith \& Pessagno (1973) reported that G. cretacea from the Late Cretaceous Corsicana Formation of Texas had a 'wall finely perforate, each pore surrounded by a blunt cone of microgranular calcite'. More recently, Loeblich \& Tappan (1987) stated that the test walls of Guembelitria are... 'finely and irregularly perforate, with each pore elevated on a pore mound' and they illustrate these features in topotype specimens of $G$. cretacea Cushman, 1933 from the Maastrichtian of Texas. Loeblich \& Tappan give the range of Guembelitria as 'L.

†Graham Jenkins died suddenly on 6th August 1995, shortly after completing this manuscript. His co-authors wish to dedicate the paper to his memory and in honour of his outstanding contributions in the field of planktonic foraminiferal research. 


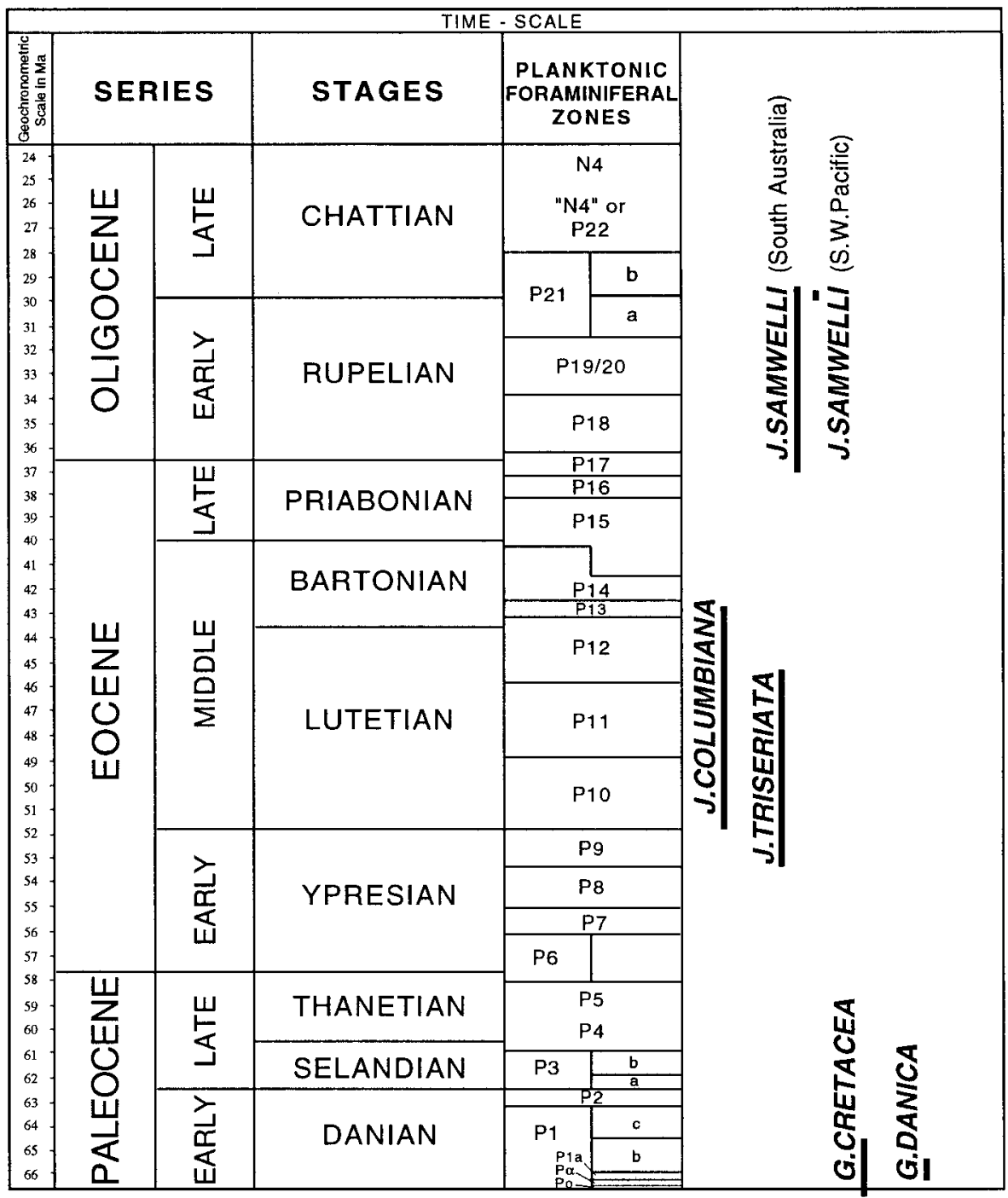

Fig. 1. Stratigraphic range chart of the species of Guembelitria and Jenkinsina plotted against the time-scale of Berggren et al. (1985). J. samwelli ranges from the late Eocene to late Oligocene in South Australia, but has a very short range within the late Oligocene in the SW Pacific. The range of G. cretacea is based on Liu \& Olsson (1992).

Cretaceous (Albian) to U. Cretaceous (Maastrichtian)', but this is no longer true. Keller (1988) showed that G. cretacea ranged into the Early Danian P1a Zone in the El Kef Section of Tunisia while Stott \& Kennett (1990) recorded it in the Early Danian AP1a Zone at ODP Site 690 on Maude Rise in the Southern Ocean, and Liu \& Olsson (1992) listed it as ranging to the top of Zone Plb (and it is this range that we have accepted on Fig. 1). Further, Koutsoukos (1994) has extended the range of the genus down to the Aptian with a description of the new species $G$. sergipensis.

We have obtained, on loan from the U.S. National Museum of Natural History, Washington, D.C., the holotype and paratype of Guembelitria cretacea Cushman (USNM nos. 19022 and 21217, respectively). For the first time, these specimens have been photographed by scanning electron microscopy and this has been achieved, without coating, using the Environmental Chamber technique described by Taylor (1986). The pore mounds can clearly be seen (pl. 1, figs 8, 9).

Loeblich \& Tappan (1987) concluded that the triserial Chiloguembelitria Hofker (1978), which was based on C. danica from the early Danian, lacked pore mounds. They illustrated supposed topotypes from an unspecified sample from DSDP Site 47.2, Shatsky Rise, in pl. 484, figs 7, 8 showing a ...'pustulose surface and absence of pore mounds'. Hofker, in his original description, had recorded that $C$. danica had...'Walls finely perforate, with small blunt pustules', and he produced two hand-drawn figures of two tests to illustrate the morphology (Hofker, 1978, pl. 4, fig. 14). These specimens were obtained from DSDP Site 47.2, sample Core 11/4/130-132, Shatsky Rise in the northern Pacific.

In order to verify the morphology of $C$. danica a search was undertaken in the Netherlands for the type specimens. The 
Palaeogene triserial planktonic foraminifera

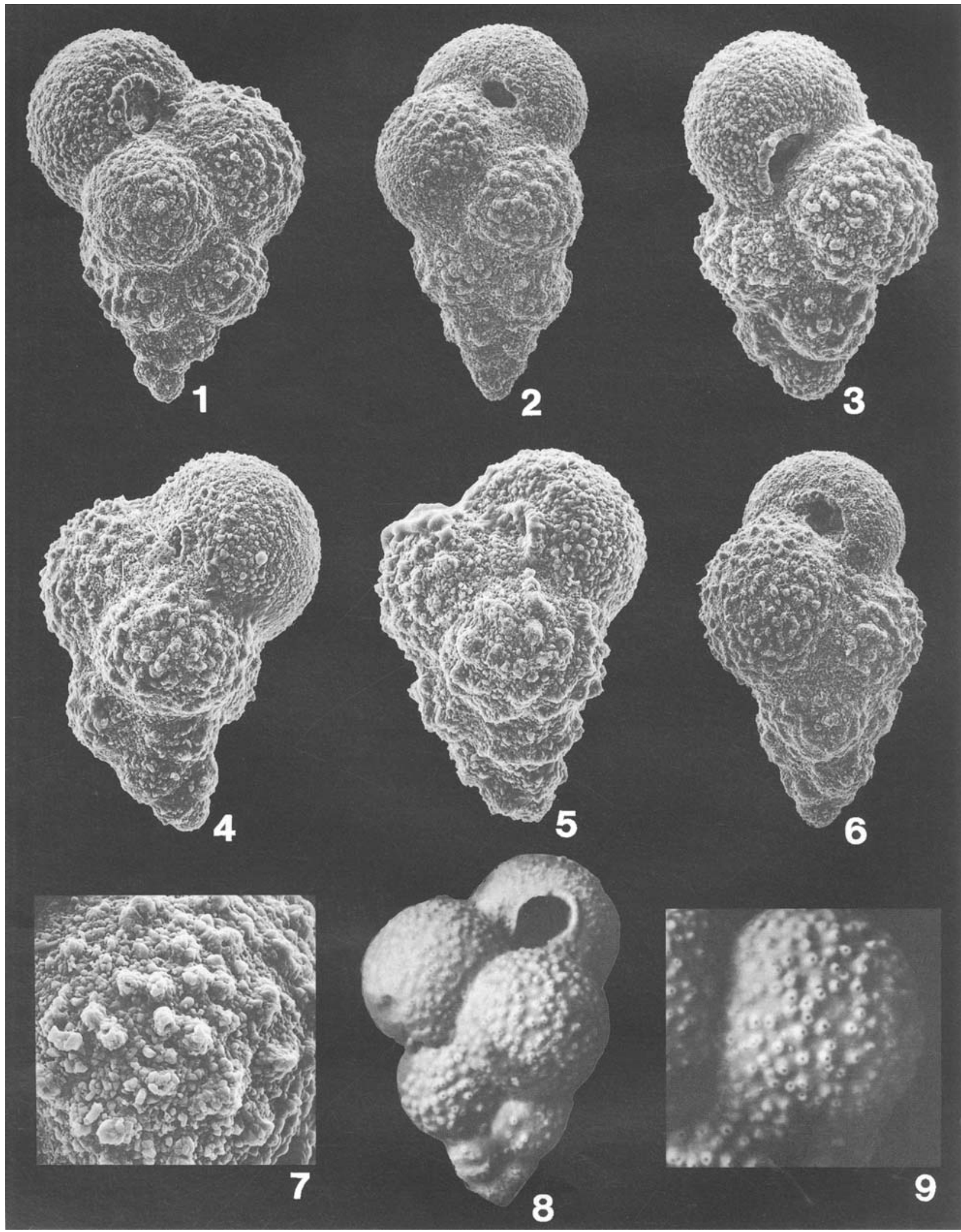

Explanation of Plate 1

Figs 1-7. Guembelitria danica (Hofker, 1978), from DSDP Site 47.2, sample Core 11/4/130-132 cms, Shatsky Rise, North Pacific, Early Danian. figs 1-6. Side views (fig. 1, Neotype, RGD no. FO-94-001, $\times 380$; figs $2-6$, RGD nos. FO-94-002-006, $\times 380, \times 505, \times 505, \times 430$, and $\times 380$, respectively). fig. 7. Close-up of penultimate chamber of RGD no. FO-94-003, showing pore mounds, $\times 1,200$. figs 8, 9. Guembelitria cretacea Cushman, 1933, from Kemp Clay, Navarro Group, McQueeny, Texas, Maastrichtian. fig. 8. Side view of Holotype (USNM no. 19022), ×405. fig. 9. Close-up of antepenultimate chamber of holotype, showing well-developed pore-mounds, $\times 630$. 
writers are grateful to Drs J. C. den Hartog (National Museum of Natural History, Leiden) and R. J. W. van Leeuwen (Geological Survey of the Netherlands, Haarlem) who looked for them. In a letter dated 23/9/1990, Dr van Leeuwen wrote...'To my regret, I have to tell you that Hofker has not deposited a type specimen of Chiloguembelitria danica in either Haarlem (Rijks Geologische Dienst) or Leiden (Rijksmuseum). I cannot think of another place in the Netherlands where he could have deposited a type, and I feel pretty sure that there is no such type'. We have also ascertained that Hofker deposited his specimens neither in the DSDP Depository at the Natural History Museum in Basel nor in the Smithsonian Institution, Washington, D.C.

Dr van Leeuwen was able to send us Hofker's original type sample, however, and from it we have picked out several specimens which resemble his illustrated specimens of $C$. danica. The test surfaces of some of the specimens exhibit diagenetic overgrowth and no doubt, because of this, Loeblich \& Tappan were misled. Better preserved specimens from the same sample, however, show clearly that the pustules on the test wall recorded by Hofker are indeed pore mounds (pl. 1, fig. 7). There is now no other consistent character by which Chiloguembelitria can be distinguished from Guembelitria. All other criteria, particularly coiling and apertural characteristics, mentioned by Hofker in his original diagnosis, are also found in Guembelitria. Chiloguembelitria therefore becomes a junior synonym of Guembelitria; the three species, $G$. cretacea, $G$. danica and $G$. irregularis Morozova, form a related group in the Early Danian. Their stratigraphic ranges were recorded by Hofker (1978), and by Keller (1988) from the El Kef Section. Because the type specimens cannot be found and because of the misunderstanding about the nature of the test surface, a neotype is here formally designated for $G$. danica.

Guembelitria danica (Hofker, 1978)

(Pl. 1, figs 1-7)

1978 Chiloguembelitria danica Hofker: 60, pl. 4, fig. 14.

1993 Guembelitria danica (Hofker); MacLeod: 47 et seq., pl. 3, figs 1,5 .

Neotype. Rijks Geologische Dienst, Haarlem, The Netherlands (RGD) no. FO-94-001. From DSDP Site 47.2 sample Core 11/4/ $130-132 \mathrm{cms}$, Shatsky Rise, northern Pacific. Early Danian (M. trinidadensis Zone).

Description. Test free, very high trochospire; dextrally coiled with apical angle of $60^{\circ}$. Wall calcareous, microperforate with pores on pore mounds. Chambers spherical in outline, about 10 forming the triserial test, increasing rapidly in size in last two whorls. Sutures shallow, rounded. Umbilicus shallow. Aperture a high rounded arch at base of final chamber opposite suture between first two chambers of the final whorl, with distinct lip. Maximum length $-170 \mu \mathrm{m}$.

Figured specimens. Five other figured specimens (pl. 1, figs 2-7) from the same sample as the neotype are deposited in the Rijks Geologische Dienst, Haarlem (RGD) nos. FO-94-002-006. Nine other (unfigured) topotypes have the RGD nos. FO-94007-015.

Remarks. According to Hofker (1978), the length of test was $100 \mu \mathrm{m}$, and therefore the neotype is somewhat longer. Four other specimens ranging in size between 130 and $170 \mu \mathrm{m}$ have also been illustrated (pl. 1, figs 2-6). The distinctive feature of the species is the elongate, high trochospire (of the triserial test), the pronounced increase in the size of the chambers in the last whorl, and the characteristic torsion of the chambers as viewed from the basal end.

Previously rather neglected, these small triserial plankton have recently received somewhat more attention. Kroon \& Nederbragt (1990) suggested that both $G$. danica and $G$. irregularis were junior synonyms of $G$. cretacea but they provided no photographic evidence to support this view. They stated that... 'both have the same shape as $G$. cretacea. We assume that both forms possess pore mounds and we regard them as synonyms of G. cretacea'. Confronted with the same problem, D'Hondt (1991) concluded: 'However, type illustrations of $C$. danica differ from the type specimens of $G$. cretacea in possessing an asymmetrically developed chiloguembelinid aperture marked by an indistinct apertural flange. In part, these taxonomic problems can be resolved by reducing Chiloguembelitria to a junior synonym of Guembelitria while provisionally retaining $G$. irregularis Morozova and $G$. danica (Hofker) as valid species'.

Most authors have continued to refer $C$. danica to Hofker's genus but Keller (1993) placed it in Guembelitria. Further, MacLeod (1993) reports that comparative morphological analysis of $G$. danica shows that, at both Nye Kløv, Denmark and ODP Site $738 \mathrm{C}$ (Kerguelen Plateau), the ' $C$. danica morphotype does exhibit well-developed pore mounds (see pl. 3 , figs 1, 5) and an apertural margin that is not qualitatively different from species belonging to either Guembelitria, Woodringia, or Chiloguembelitria'. As there are therefore no consistent criteria by which the two can be differentiated, we support D'Hondt, Keller and MacLeod in synonymizing Chiloguembelitria with Guembelitria.

The most detailed study of the comparative morphology of Guembelitria species is that of MacLeod (1993). Following cladistic analysis of 52 morphological characters representing all ontogenetic stages, he concluded that cretacea and danica were indeed distinct species. The alternative view, as discussed above, is that $G$. danica is a junior synonym of $G$. cretacea. A definitive answer is beyond the scope of this paper, whose aim is primarily to focus on generic criteria. We have, however, chosen and figured a neotype of $G$. danica (pl. 1, fig. 1) so that a direct comparison can now be made with the holotype of $G$. cretacea, here photographed for the first time by SEM (pl. 1, figs 8 and 9). Stratigraphic range. Hofker (1978) recorded $G$. danica in the Early Danian trinidadensis Zone at DSDP Site 47.2, Shatsky Rise. D'Hondt (1991) gives its range as P0- $P$. eugubina zones in the El Kef Section and P0-M. pseudobulloides zones, both in the Danian, at DSDP Site 528. Keller (1993) gives a range from P0a to P1c in the Early Danian of the El Kef Section of Tunisia. See also Figure 1 for ranges of $G$. danica and $G$. cretacea.

\section{Jenkinsina}

Haynes (1981) erected Jenkinsina (with Guembelitria stavensis Bandy as the type species) as it was... 'different in wall structure [to Guembelitria] and lack[ed] pore mounds'.

$J$. stavensis is here regarded as a junior synonym of $J$. triseriata (Terquem), this opinion being based on the re- 


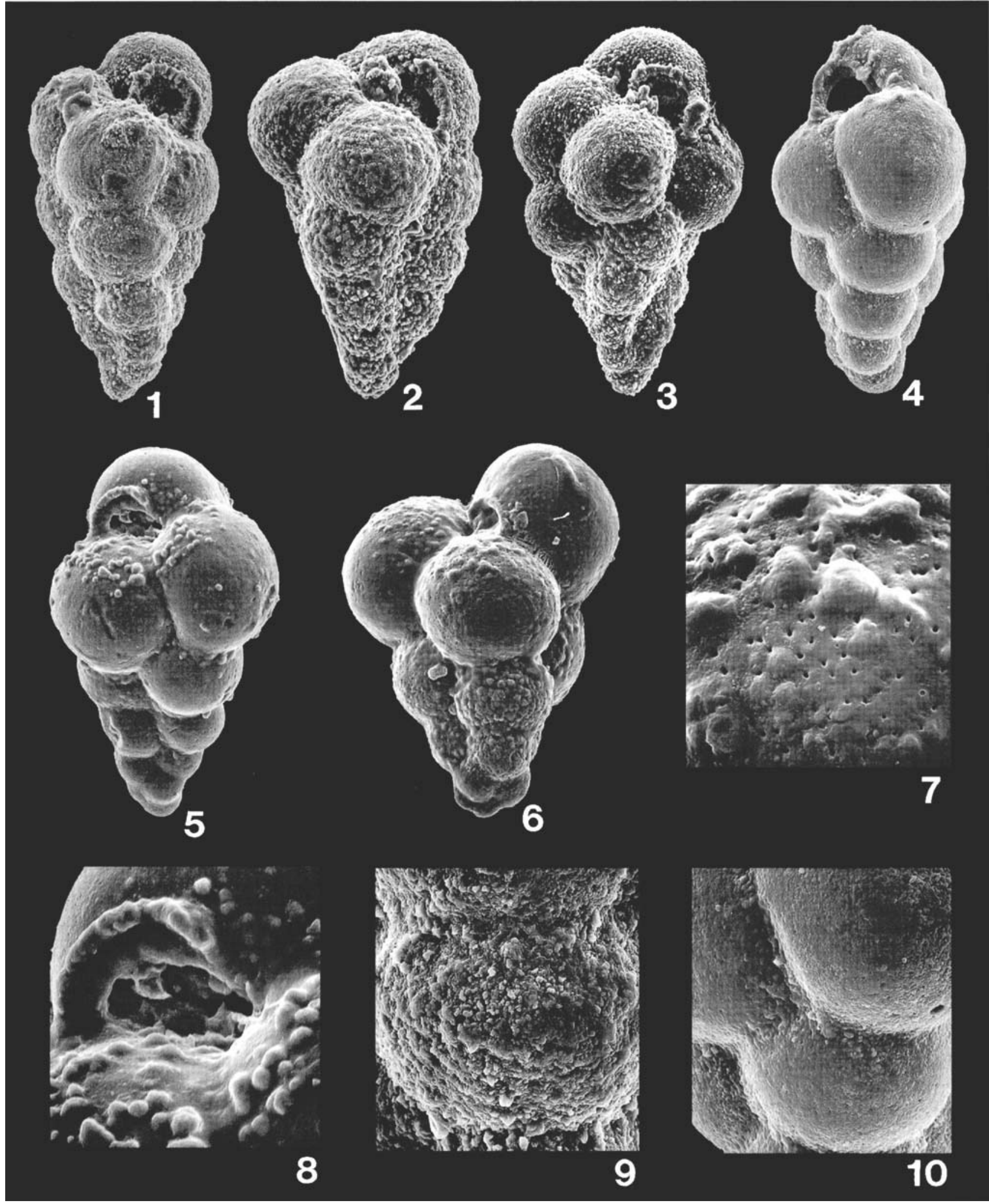

Explanation of Plate 2

Figs 1-4, 9, 10. Jenkinsina triseriata (Terquem, 1882), from Liancourt St. Pierre, N. France, Middle Lutetian. figs 1-4. Side views (1, Neotype, BMNH no. PF 52918, $\times 405$; figs 2-4, BMNH nos. PF 52919-52921, $\times 520, \times 430$, and $\times 560$, respectively). figs 9 , 10. Close-ups to show microperforate wall in two different states of preservation, BMNH nos. PF 52918 and 52921, respectively, $\times 1,150$. figs 5, 8. Jenkinsina triseriata (Terquem, 1882), from Bracklesham Bed W12 (Wittering Formation), Selsey, S. England, Early Eocene. fig. 5. BMNH no. PF 52922, side view, $\times 405$. fig. 8. Same specimen, detail of aperture, $\times 1,150$. figs 6, 7. Guembelitria oveyi Ansary, 1955, from near Wadi Tayibi, Sinai, Egypt, Late Eocene. fig. 6. Holotype (BMNH no. P 40980), side view, $\times 405$. fig. 7 . Holotype, detail of microperforate wall, $\times 1,950$. 
examination of topotypes of the former (Jenkins, 1978a). Two other species are described and discussed: $J$. columbiana (Howe) and $J$. samwelli (Jenkins). Both $J$. triseriata and $J$. columbiana lived at the same time in the Early-Middle Eocene and occurred, for example, in the same general geographic area of Louisiana and Alabama, USA. $J$. samwelli, on the other hand, lived only in the Southern Hemisphere during the later part of the Late Eocene to the early part of the Late Oligocene.

\section{Jenkinsina triseriata (Terquem, 1882)}

(Pl. 2, figs $1-5,8-10)$

1882 Textilaria triseriata Terquem: 145 , pl. 15 , fig. 10 .

1949 Gümbelitria stavensis Bandy: 124, pl. 24, fig. 5.

1955 Gümbelitria oveyi Ansary: 79, pl. 2, fig. 31.

1969 Guembelitria triseriata (Terquem); Bignot \& Le Calvez: 162

1970 Guembelitria triseriata (Terquem); Le Calvez: 171, pl. 36, fig. 6.

1978a Guembelitria stavensis Bandy; Jenkins: 687, pl. 1, figs 9 13.

1989 Guembelitria triseriata (Terquem); Murray et al:: 532, pl. 10.11 , figs 5,6

1990 Guembelitria triseriata (Terquem); Willems: 406, pl. 10, fig. 1.

1990 Chiloguembelitria sp.? Stott \& Kennett: 559, pl. 5, fig. 9. 1991 Guembelitria columbiana Howe; Huber: 440, pl. 6, fig. 1. Neotype. The Natural History Museum [BMNH], London, no. PF 52918. From Liancourt St. Pierre (Oise), Paris Basin, France. Early-Middle Eocene (Middle Lutetian; Zone 4).

Description. Test free, very high trochospire; sinistrally coiled, with an apical angle of $35^{\circ}$. Wall calcareous, microperforate with rounded pores. Chambers spherical in outline, about 13-15 forming the triserial test in five whorls, slightly twisted about the coiling axis, increasing slowly in size. Sutures shallow, rounded. Umbilicus shallow. Aperture a high rounded arch, rimmed by a conspicuous lip, positioned above the suture separating the first chamber of the final whorl and the last chamber of the previous whorl. Maximum length $-160 \mu \mathrm{m}$.

Figured specimens. Three other figured specimens from Liancourt St. Pierre and one from Selsey, S. England (pl. 2, figs 1-5, 8-10) are deposited in the Natural History Museum [BMNH], London, nos. PF 52919-52922.

Remarks. In September 1988 a visit was made by DGJ to the Muséum National d'Histoire Naturelle, Paris in order to examine the types of Jenkinsina triseriata (Terquem). In the Terquem Collection there were three specimens labelled Textilaria triseriata: (1) a small triserial calcareous specimen, possibly a Reussella with an incipient keel; (2) a similarly sized, poorly preserved specimen, also triserial but with rounded chambers embedded in and obscured by Canada Balsam, and (3) a specimen in a tube labelled 'FT34 315.10 ', which appears to be a Jenkinsina but with the last few chambers broken off. After a comparison with Terquem's (1882) figure (pl. 15, fig. 10), it can reasonably be concluded that the third is probably the original figured specimen; Le Calvez (1970) had already come to this conclusion, although to refer to this last specimen as the holotype, as she did, is not strictly correct.

According to Dr M.-T. Vénec-Peyré of the Paris Museum, the type locality at Vaudancourt (Oise) is no longer exposed, but she was able to supply us with two small topotype samples from the Le Calvez Collection. Both samples yielded shallow water benthonic foraminifera and fragments of bivalves, gastropods and bryozoa, but unfortunately, no specimens of $J$. triseriata were found.

Because of the damaged nature of the only syntype that can definitely be ascribed to Terquem's taxon (the last few chambers are missing and the aperture cannot be seen), a case has been submitted to the ICZN to set aside this specimen in favour of a proposed neotype (pl. 2, fig. 1) from a locality near to Vaudancourt and from the same stratigraphical level. Liancourt St. Pierre (Oise) is $c .11 \mathrm{~km}$ west of Vaudancourt and the samples have yielded abundant specimens of $J$. triseriata (Terquem).

Of the three other specimens illustrated from Liancourt St Pierre (pl. 2, figs 2-4), two are sinistrally coiled and one is dextral; they range in size from 115 to $150 \mu \mathrm{m}$. The wall structure of the neotype and two specimens figured in pl. 2, figs 2,3 is masked by an overgrowth of calcite crystals (e.g. pl. 2, fig. 9) but in the smallest specimen (pl. 2, fig. 4) it is smooth, similar to a specimen from the Middle Eocene of Selsey, southern England (pl. 2, fig. 5), which also has pustules on the final whorl. A close-up of the wall, especially of the smooth specimens, shows the minute perforations (pl. 2, fig. 10). The apertural position in the two other Liancourt specimens (pl. 2, figs 2 and 3 ) is similar to the neotype, but in the smallest specimen it is much more umbilical in position (pl. 2, fig. 4); this could be an ontogenetic difference. All the specimens, in side view, show the whorls to have a slightly twisted appearance.

Bignot \& Le Calvez (1969) recorded $J$. triseriata from the Cuisian and Lutetian of the Paris Basin, and Le Calvez (1970) illustrated a specimen from the Lutetian of the Paris Basin but unfortunately the final chambers are also broken. Willems \& Moorkens (1990) recorded the first appearance of $J$. triseriata in the upper part of the Flanders Clay Member, Early Eocene of the Belgian Basin, and Willems (1990) illustrated the species from the Kallo Well in Belgium from a sample at $242.5 \mathrm{~m}$, in the upper part of the Early Eocene. Nocchi et al. (1991) recorded Guembelitria spp. from the Early-Middle Eocene at ODP Sites 699, 700, 702 and 703 in the South Atlantic and illustrated a possible $J$. triseriata from the Early-Middle Eocene of Site 703.

Li \& Radford (1991) published a modern map showing the distribution of ' $G$. triseriata' from publications of various authors; in this they included references to $G$. columbiana Howe (see below) as they considered it to be a junior synonym of triseriata (Radford, pers. comm.). From their own work, Li \& Radford have recorded $G$. triseriata from the Middle Eocene of ODP Site 749, drilled on the Kerguelen Plateau, southern Indian Ocean.

Comparison with other species. Guembelitria stavensis Bandy (1949), described from the Middle Eocene of Alabama, is here regarded as a junior synonym of $J$. triseriata; Le Calvez (1970) was also of the same opinion. The similarity of the tests can be confirmed by examining the illustrations of topotypic specimens of $J$. stavensis in Jenkins (1978a).

Guembelitria samwelli Jenkins (1978b) was originally described from the Late Oligocene $G$. euapertura Zone of New Zealand and is widely distributed in the Oligocene of the Southern Hemisphere (Jenkins, 1993). This species is also a 
Jenkinsina and differs from $J$. triseriata in normally having: (1) a smaller and more rounded aperture, positioned opposite the suture separating the penultimate chamber and the first chamber of the final whorl [Jenkins, $1978 b$ and Jenkins \& Srinivasan (1985) illustrated a specimen with an enlarged aperture]; (2) a less thickened apertural lip; (3) in not having the chambers slightly twisted about the coiling axis, and (4) in possessing the occasional supplementary aperture (see Jenkins, 1978b, pl. 1, figs 1, 4 and 5).

Guembelitria columbiana Howe (1939), originally described from the Middle Eocene of Louisiana, differs from $J$. triseriata in having: (1) a much smaller test (pl. 3, figs 1-5); (2) only three whorls in triserial tests with a conical angle of $62^{\circ}$; and (3) a pustular test wall. See below for further details.

Guembelitria oveyi Ansary (1955) was described from the Late Eocene of Egypt, but according to Prof. H. Luterbacher (pers. comm.) 'the lithologic unit from which $G$. oveyi was described by Ansary is now placed in the Middle Eocene'. Le Calvez (1970) regarded it as a junior synonym of $J$. triseriata. The holotype is refigured here (pl. 2, figs 6 and 7) for comparison; it is certainly very similar to $J$. triseriata.

Stratigraphic/palaeogeographic distribution. J. triseriata has been recorded at the following localities: Paris Basin - Middle Eocene (Terquem, 1882; Bignot \& Le Calvez, 1969; Le Calvez, 1970); Egypt - Middle Eocene (Ansary, 1955); Southern England - late Early Eocene-Middle Eocene (Murray et al., 1989); Maude Rise, Southern Indian Ocean (Stott \& Kennett, 1990); Kerguelen Plateau, Southern Indian Ocean - late Early to early Middle Eocene (Huber, 1991), Middle Eocene (Li \& Radford, 1991).

\section{Jenkinsina columbiana (Howe, 1939) (Pl. 3, figs 1-5)}

1939 Gümbelitria columbiana Howe: 6, pl. 8, figs 12, 13. 1945 Gümbelitria columbiana Howe; Cushman \& Todd: 16, pl. 4, fig. 3.

1957 Guembelitria columbiana Howe; Beckmann: 92, pl. 21, fig. 16.

Description. Test free, small, triangular shaped outline, with an apical angle of $62^{\circ}$ and a lobulate periphery. Wall calcareous, microperforate, pustular. Chambers globular, spherical in outline, coiled triserially, with about nine forming the test, increasing rapidly in size. Sutures fairly deep. Umbilicus open. Aperture a low arch at base of final chamber, with a distinct irregular flanged lip. Length of holotype recorded by Howe (1939) as $150 \mu \mathrm{m}$.

Type locality. Cook Mountain Formation, Louisiana, U.S.A. Claiborne Series, Middle Eocene.

Figured specimens. Two specimens from Selsey, S. England (pl. 3, figs 1, 2, 4 and 5) and one from Peyreblanque, Biarritz, S.W. France (pl. 3, fig. 3), both Middle Eocene in age, are deposited in the Natural History Museum [BMNH], London, nos. PF 5292352925.

Remarks. J. columbiana has a distinctive triserial test with chambers rapidly expanding in size and with an apical angle of $62^{\circ}$, which is in marked contrast to $J$. triseriata with an angle of $35^{\circ}$. Kroon \& Nederbragt (1990), nevertheless, regarded it as the senior synonym of both J. stavensis (Bandy) and J. samwelli
(Jenkins). Masters (1977), on the other hand, after examining the holotype of columbiana, concluded that it was identical to $G$. cretacea Cushman.

Stratigraphic/palaeogeographic distribution. According to Prof. W. A. Berggren (pers. comm.), the type locality of $J$. columbiana (Cook Mountain Formation) is roughly equivalent to Zone NP16 (Middle Eocene). In Trinidad, Beckmann (1957) recorded this species from the Middle Eocene $H$. aragonensis $-P$. mexicana zones (P10-13). In England, it occurs in the Middle Eocene Bracklesham Group (Fisher Bed $19 \approx$ S8) (see pl. 3, figs 1 and 2), which is equivalent to Zone NPI5 (Curry et al., 1978); similar specimens occur at about the same stratigraphic level at Peyreblanque, Biarritz, S.W. France (pl. 3, fig. 3). The European stratigraphic range is equivalent only to about the upper part of its Trinidad range (Fig. 1) and in England $J$. triseriata (NP12-14) does not overlap the range of $J$. columbiana (NP15).

\section{Jenkinsina samwelli (Jenkins, 1978b)}

(Pl. 3, figs 6-8)

1974 Gümbelitria stavensis Bandy; Jenkins: 371-373, fig. 1.

1978 a Guembelitria aff. stavensis Bandy; Jenkins: 687-693, pl. 1, figs $1-8$.

1978 buembelitria samwelli Jenkins: 132-137, pl. 1, figs 1-9.

1985 Jenkinsina samwelli (Jenkins); Jenkins \& Srinivasan: 813,

pl. 5, fig. 9 .

Holotype description. Test free, small elongate tetrahedron with a lobate periphery and an apical angle of $c .36^{\circ}$. Wall calcareous, perforate with irregular pores between minute calcite plates. Chambers triserially coiled, sinistral, about 14 forming the test in four whorls; chambers increase slowly in size. Sutures shallow in earliest part of test but more pronounced in later whorls. Umbilicus open. Aperture small, $10 \mu \mathrm{m}$ high, arched with rim extending from antepenultimate chamber to more than halfway along the arch; umbilical, at base of final chamber. Maximum length of test $160 \mu \mathrm{m}$, maximum width $110 \mu \mathrm{m}$.

Type locality. The holotype was obtained from a Late Oligocene $G$. euapertura zone sample from the west coast of the South Island, New Zealand and SEM illustrations were provided by Jenkins (1978b); holotype and paratypes deposited in the collections of the New Zealand Geological Survey, Lower Hutt, nos. TF $1583 / 1$ and TF $1583 / 2-42$, respectively.

Figured specimen. From DSDP Site 593, off the west coast of South Island of New Zealand, Late Oligocene. Deposited in The Natural History Museum [BMNH], London, no. PF 52926. Three other (unfigured) specimens from the same locality have the registration nos. PF 52927-52929.

Stratigraphic/palaeogeographic distribution. This species has been recorded (but not illustrated) by Lindsay (1969) and by Ludbrook \& Lindsay (1969) (as G. stavensis), and by McGowran \& Beecroft (1986) (as $G$. triseriata) from the uppermost Late Eocene to the lower part of the Late Oligocene of South Australia. All other records from the Southern Hemisphere are from the early part of the Late Oligocene and include: New Zealand; Southwest Pacific DSDP Sites 276, 277, 282 and 593; South Atlantic DSDP Site 360 (Jenkins, 1993) and ODP Site 704 (Nocchi et al., 1991); South Indian Ocean Site 754A (P. Gamson, pers. comm.; Jenkins, 1993). 


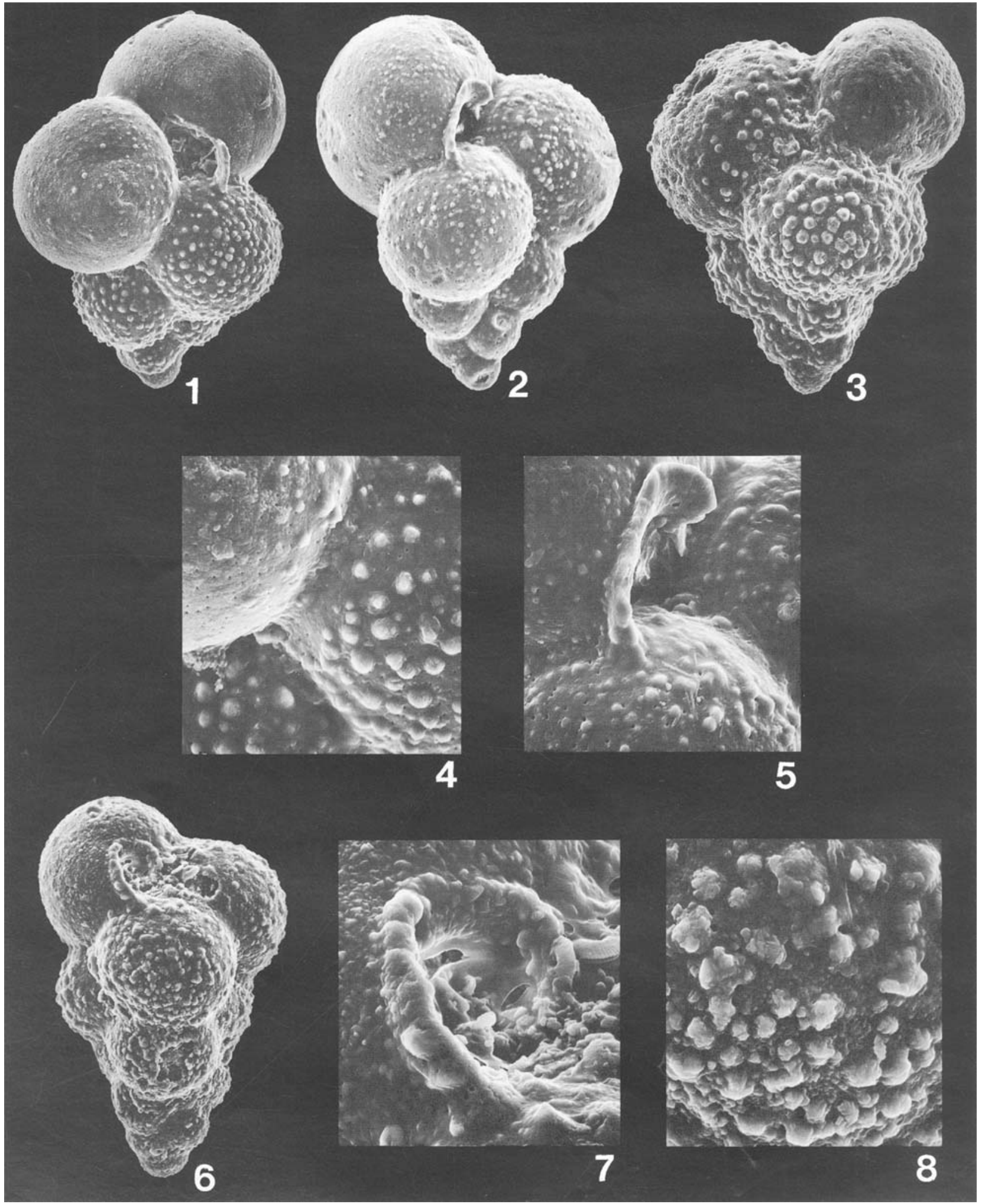

Explanation of Plate 3

Figs 1, 2, 4, 5. Jenkinsina columbiana (Howe, 1939), from Bracklesham Bed S8 (Selsey Sand Formation), S. England, Middle Eocene. figs 1, 4. BMNH no. PF 52923, side view $(\times 430)$ and detail of microperforate wall $(\times 1,150)$, respectively. figs 2,5 . BMNH no. PF 52924, side view $(\times 480)$ and close-up showing aperture and detail of microperforate wall $(\times 1,150)$, respectively. fig. 3. Jenkinsina columbiana (Howe, 1939), from Peyreblanque, Biarritz, SW France, Middle Eocene. BMNH no. PF 52925, side view $(\times 450)$. figs 6-8. Jenkinsina samwelli (Jenkins, 1978), from DSDP Site 593, off South Istand, New Zealand, Late Oligocene. fig. 6. BMNH no. PF 52926, side view, $\times 540$. figs 7. 8. Same specimen. close-up of aperture $(\times 2,000)$ and detail of microperforate wall and surface texture $(\times 2,250)$, respectively. 
$J$. samwelli lived in the Austral Gulf between Australia and Antarctica from the Late Eocene to early Late Oligocene. When the two continents finally became detached at the Tasman Rise, the water flowed out into the Southwest Pacific and also carried the plankton around Antarctica, and through the Drake Passage into the South Atlantic and South Indian Ocean. J. samwelli lived for only a brief period of time and its migration marks the beginning of the circum-Antarctic current at c. 30-31 Ma (Jenkins, 1974, 1978a, 1978b, 1993; Jenkins \& Srinivasan, 1985). The species had a northern limit of latitude $35^{\circ} \mathrm{S}$ in the South Atlantic and latitude $40^{\circ} \mathrm{S}$ in the South Pacific.

\section{PHYLOGENY}

Olsson et al. (1992) derive a number of microperforate genera from Guembelitria in the Danian P0 Zone, but only the trochospirally coiled Parvularugoglobigerina which ranged into the P2 Zone retained some pore mounds. The other genera Chiloguembelina, Woodringina and Globoconusa do not have pore mounds. Thus Guembelitria cretacea is the last triserial taxon which had the distinctive pore mounds, and from the published data and from our own research it would seem that pore mounds disappeared with the extinction of $G$. cretacea and $P$. eugubina.

There is no direct phylogenetic connection between the triserial Danian Guembelitria and the Early Eocene Jenkinsina taxa. Consequently, we can postulate that the Jenkinsina species evolved directly from microperforate taxa which did not possess pore mounds. An ancestral candidate for Jenkinsina is the biserial genus Chiloguembelina and as can be seen from Fig. 1, the Jenkinsina triserial test may have evolved twice, once in the Early Eocene and then again in the Late Eocene. To check this hypothesis, however, more work is required into the late Middle to Late Eocene planktonic assemblages.

Our contention that pore mounds were finally lost in the early Palaeocene is reinforced by the work of Li \& Radford (1994) who redescribed Cassigerinelloita amekiensis Stolk, an EarlyMiddle Eocene microperforate taxon with triserial-planispiral coiling and which they derive from $J$. triseriata; it does not possess pore mounds.

\section{CONCLUSIONS}

Palaeogene triserial planktonic foraminiferal species can be classified into Guembelitria (Early Danian) and Jenkinsina (Eocene-Oligocene); Guembelitria is distinguished from Jenkinsina in possessing pore mounds. On present evidence, there does not seem to be any phylogenetic connection between the two genera (Fig. 1). Future research should try to establish if Guembelitria and Jenkinsina are related and whether Jenkinsina evolved from Chiloguembelina or from some other genus in the Early Eocene.

\section{ACKNOWLEDGEMENTS}

DGJ wishes to thank Dr M.-T. Vénec-Peyré of the Institut de Paléontologie, Muséum National d'Histoire Naturelle, Paris for her patience in searching for Terquem's types of $J$. triseriata; he also visited the National Museum of Natural History, Smithsonian Institution, Washington, D.C. to examine other type specimens and wishes to thank Dr B. Huber for his kindness and cooperation. The authors wish to thank Drs J. C. den
Hartog (National Museum of Natural History, Leiden) and R. J. W. van Leeuwen (Rijks Geologische Dienst, Haarlem) for their cooperation in the search for the types of Hofker's $C$. danica. The paper also benefited from several discussions with Dr N. MacLeod, now at the Natural History Museum, London.

\section{Manuscript received January 1996 Manuscript accepted May 1996}

\section{REFERENCES}

Ansary, S. E. 1955. Report on the foraminiferal fauna from the Upper Eocene of Egypt. Publications de l'Institut du Désert d'Égypte, 6: 1160.

Bandy, O. L. 1949. Eocene and Oligocene foraminifera from Little Stave Creek, Clarke County, Alabama. Bulletins of American Paleontology, 32(131): 1-210.

Beckmann, J. 1957. Chiloguembelina Loeblich and Tappan and related foraminifera from the Lower Tertiary of Trinidad, B.W.I. Bulletin of the U.S. National Museum, 215: 83-95.

Berggren, W. A., Kent, D. V. \& Flynn, J. J. 1985. Jurassic to Palaeogene: Part 2. Palaeogene geochronology and chronostratigraphy. In Snelling, N.J. (Ed.), The Chronology of the Geological Record, 141-198. Blackwell Scientific Publications, Oxford. (Memoir of the Geological Society of London, 10).

Bignot, G. \& Le Calvez, Y. 1969. Contribution à l'étude des foraminifères planctoniques de l'Eocene du Basin de Paris. In Brönnimann, P. \& Renz, H. H. (Eds), Proceedings of the First International Conference on Planktonic Microfossils, Geneva, 1: 161166. E. J. Brill, Leiden.

Curry, D., Adams, C. G., Boulter, M. C., Dilley, F. C., Eames, F. E., Funnell, B. M. \& Wells, M. K. 1978. A correlation of Tertiary rocks in the British Isles. Geological Society of London, Special Report, 12: 172.

Cushman, J. A. 1933. Some new foraminiferal genera. Contributions from the Cushman Laboratory for Foraminiferal Research, 9: 32-38.

Cushman, J. A. 1934. A Recent Gümbelitria(?) from the Pacific. Contributions from the Cushman Laboratory for Foraminiferal Research, 10: 105.

Cushman, J. A. \& Todd, R. 1945. A foraminiferal fauna from the Lisbon Formation of Alabama. Contributions from the Cushman Laboratory for Foraminiferal Research, 21: 11-21.

D'Hondt, S. 1991. Phylogenetic and stratigraphic analysis of earliest Palaeocene biserial and triserial planktonic foraminifera. Journal of Foraminiferal Research, 21: 168-181.

Haynes, J. R. 1981. Foraminifera. MacMillan, London, 433 p.

Hofker, J. 1978. Analysis of a large succession of samples through the Upper Maastrichtian and Lower Tertiary of Drill Hole 47.2, Shatsky Rise, Pacific, Deep Sea Drilling Project. Journal of Foraminiferal Research, 8: 46-75.

Howe, H. V. 1939. Louisiana Cook Mountain Eocene foraminifera. Bulletin of the Geological Survey of Louisiana, 14: 1-122.

Huber, B. T. 1991. Palaeogene and early Neogene planktonic foraminifer biostratigraphy of Sites 738 and 744, Kerguelen Plateau (southern Indian Ocean). Proceedings of the Ocean Drilling Program, Scientific Results, 119: 427-449.

Jenkins, D. G. 1965. Planktonic foraminifera and Tertiary intercontinental correlation. Micropaleontology, 11: 265-277.

Jenkins, D. G. 1974. Initiation of the protocircum-Antarctic current. Nature, 252: 371-373.

Jenkins, D. G. 1978a. Guembelitria aff. stavensis Bandy, a paleooceanographic marker of the initiation of the circum-Antarctic current and the opening of the Drake Passage. Initial Reports of the Deep Sea Drilling Project, 40: 687-693.

Jenkins, D. G. 1978b. Guembelitria samwelli Jenkins, a new species from the Oligocene of the Southern Hemisphere. Journal of Foraminiferal Research, 8: 132-137.

Jenkins, D. G. 1993. The evolution of the Cenozoic southern high- and mid-latitude planktonic foraminiferal faunas. Antarctic Research Series, 60: 175-194.

Jenkins, D. G. \& Srinivasan, M. S. 1985. Cenozoic planktonic 
foraminifera from the Equator to the Sub-Antarctic of the Southwest Pacific. Initial Reports of the Deep Sea Drilling Project, 90: 795-834.

Keller, G. 1988. Extinction, survivorship and evolution of planktic foraminifera across the Cretaceous/Tertiary boundary at El Kef, Tunisia. Marine Micropaleontology, 13: 239-263.

Keller, G. 1993. The Cretaceous-Tertiary boundary transition in the Antarctic Ocean and its global implications. Marine Micropaleontology, 21: $1-45$.

Koutsoukos, E. A. 1994. Early stratigraphic record and phylogeny of the planktonic genus Guembelitra Cushman, 1933. Journal of Foraminiferal Research, 24: 288-295.

Kroon, D. \& Nederbragt, A. J. 1990. Ecology and paleoecology of triserial planktic foraminifera. Marine Micropaleontology, 16: 25-38

Le Calvez, Y. 1970. Contribution à l'étude des foraminiferes paléogènes du Bassin de Paris. Éditions du Centre National de la Recherche Scientifique, Paris, 326 p.

Li Qianyu \& Radford, S. S. 1991. Evolution and biogeography of Palaeogene microperforate planktonic foraminifera. Palaeogeography. Palaeoclimatology and Palaeoecology, 83: 87-115.

Li Qianyu \& Radford, S. S. 1994. Notes on the topotype and deep-sea specimens of the planktonic foraminifer Cassigerinelloita amekiensis Stolk. Journal of Micropalaeontology, 13: 157-159.

Li Qianyu, McGowran, B. \& Boersma, A. 1995. Early Palaeocene Parvularugoglobigerina and late Eocene Praetenuitella: does evolutionary convergence imply similar habitat? Journal of Micropalaeontology, 14: 119-134.

Lindsay, J. M. 1969. Cenozoic foraminifera and stratigraphy of the Adelaide Plains Sub-basin, South Australia. Bulletin of the Geological Survey of South Australia, 42: 1-60.

Liu, C. \& Olsson, R. K. 1992. Evolutionary radiation of microperforate planktonic foraminifera following the $K / T$ mass extinction event Journal of Foraminiferal Research, 22: 328-346.

Loeblich, A. R. \& Tappan, H. 1987 (1988). Foraminiferal Genera and their Classification. Van Nostrand Reinhold, New York. 2 vols, 970 pp.

Ludbrook, N. \& Lindsay, J. M. 1969. Tertiary foraminiferal zones in South Australia. In Brönnimann, P. \& Renz, H. H. (Eds), Ist International Conference on Planktonic Microfossils, Geneva, Vol 2 , 366-375. E. J. Brill, Leiden.

MacLeod, N. 1993. The Maastrichtian-Danian radiation of triserial and biserial planktic foraminifera: Testing phylogenetic and adaptational hypotheses in the (micro) fossil record. Marine Micropaleontology, 21: $47-100$.
Masters, B. A. 1977. Mesozoic planktonic foraminifera. In Ramsay, A.T.S. (Ed.), Oceanic Micropalaeontology, 1: 301-731. Academic Press, London.

McGowran, B. 1968. Reclassification of Early Tertiary Globorotalia. Micropaleontology, 14: 179-198.

McGowran, B. \& Beecroft, A. 1986. Guembelitria in the Early Tertiary of Southern Australia and its paleoceanographic significance N.H. Ludbrook Honour Volume. Special Publication of the South Australia Department of Mines and Energy, 5: 247-261.

Murray, J. W. Curry, D., Haynes, J. R. \& King, C. 1989. Palaeogene. In Jenkins, D. G. \& Murray, J. W. (Eds), Stratigraphical Atlas of Fossil Foraminifera, 2nd edn, 490-536. Ellis Horwood, Chichester.

Nocchi, M., Amici, E. \& Premoli Silva, I. 1991. Planktonic foraminiferal biostratigraphy and paleoenvironmental interpretation of Palaeogene faunas from the Subantarctic transect, Leg 114, Ocean Drilling Program. Proceedings of the Ocean Drilling Program, Scientific Results, 114: 233-279.

Olsson, R. K. 1970. Planktonic foraminifera from base of Tertiary, Miller's Ferry, Alabama. Journal of Paleontology, 44: 598-604.

Olsson, R. K., Hemleben, C., Berggren, W. A. \& Liu, C. 1992. Wall texture classification of planktonic foraminiferal genera in the Lower Danian. Journal of Foraminiferal Research, 22: 195-213.

Smith, C. C. \& Pessagno, E. A. 1973. Planktonic foraminifera and stratigraphy of the Corsicana Formation (Maestrichtian), northcentral Texas. Cushman Foundation for Foraminiferal Research, Special Publication, 12: 1-68.

Steineck, P. L. \& Fleisher, R. L. 1978. Towards a classical evolutionary reclassification of Cenozoic Globigerinacea (Foraminiferida). Journal of Paleontology, 52: 618-635.

Stott, L. D. \& Kennett, J. P. 1990. Antarctic Palaeogene planktonic foraminiferal biostratigraphy: ODP Leg 113 , sites 689 and 690 . Proceedings of the Ocean Drilling Program, Scientific Results, 113: $549-569$

Taylor, P. D. 1986. Scanning electron microscopy of uncoated fossils. Palaeontology, 29: 685-690.

Terquem, O. 1882. Les foraminifères de l'Éocène des environs de Paris. Mémoires de la Société Géologique de France, Ser. 3, 2: 1-193.

Willems, W. 1990. Iconography of the Ypresian foraminifera of the Belgian Basin and description of new benthonic species. In Dupuis, C. \& Deconinck, J. (Eds), The Ypresian Stratotype. Bulletin de la Sociéte Belge de Géologie, 97(3/4) (for 1988): 385-435.

Willems, W. \& Moorkens, T. 1990. The Ypresian Stage of the Belgian Basin. In Dupuis, C. \& Deconinck, J. (Eds), The Ypresian Stratotype. Bulletin de la Société Belge de Géologie, 97(3/4) (for 1988): 231-249. 